\title{
Translocation and bioaccumulation of trace metals from industrial effluent to locally grown vegetables and assessment of human health risk in Bangladesh
}

\author{
Md. Didarul Islam ${ }^{1}$. M. Mehedi Hasan ${ }^{2} \cdot$ Ashiqur Rahaman $^{3} \cdot$ Papia Haque $^{1} \cdot$ Md. Sazedul Islam $^{1}$. \\ Mohammed Mizanur Rahman ${ }^{1}$
}

Received: 8 March 2020 / Accepted: 20 June 2020 / Published online: 1 July 2020

(c) Springer Nature Switzerland AG 2020

\begin{abstract}
In this study, we evaluated the level of trace metals in the soil of heavily loaded tannery and battery industry area on the bank of the Buriganga River, Dhaka, Bangladesh in order to investigate their translocation to the locally grown vegetables and potential health risk of the local consumers. Concentrations of various metals in agricultural soil and in a number of vegetables such as; Red amaranth (Amaranthus cruentus), Spinach (Spanacia oleracea), Jute leaf (Corchorus capsularies), Bottle Gourd (Lagenaria siceraria), Mustard green (Brassica juncea) and Water spinach (Impomoea aquatica) were determined by atomic absorption spectrometry. The content of chromium ( $\mathrm{Cr}$ ), nickel (Ni), copper (Cu), zinc ( $\mathrm{Zn}$ ), cadmium (Cd), and lead $(\mathrm{Pb})$ in the soil was around 500,50,50, 40, 0.8 and $200 \mathrm{mg} / \mathrm{kg}$, respectively. $\mathrm{Cr}$ and $\mathrm{Pb}$ were found in the locally grown vegetables around 20 and $0.5 \mathrm{mg} / \mathrm{kg}$ respectively, which are higher than the permissible limit of them $(2 \mathrm{mg} / \mathrm{kg}$ for $\mathrm{Cr}$ and $0.3 \mathrm{mg} / \mathrm{kg}$ for $\mathrm{Pb}$ ) in vegetables as recommended by FAO/WHO and the data confirm the translocation of the metals from the soil to the vegetables. Hazard index value of all the vegetables considered was above 1, which indicates that the people could experience severe health risk due to consumption of any of those vegetables. Total cancer risk (TCR) value was obtained for $\mathrm{Cr}, \mathrm{Ni}$ and $\mathrm{Pb}$ content in the local vegetables and it was observed that the value was around $1 \times 10^{-3}$ for all of the sample vegetables. The high TCR values (higher than the USEPA threshold level of $1 \times 10^{-6}$ ) indicate that there is a potential cancer risk due to intake of vegetables grown in that area.
\end{abstract}

Keywords Trace metals · Potential health risk · Estimated daily intake $\cdot$ Hazard index $\cdot$ Hazard quotient $\cdot$ Total cancer risk

\section{Introduction}

Tannery industries are one of the oldest industries in Bangladesh. From the beginning to the present day, these industries are playing a crucial role in the economy of Bangladesh due to its large potential for employment, GDP growth and export. According to the Bangladesh Exports Promotion Bureau, in the fiscal year 2016-2017 (July-June), export earnings from the leather goods and footwear sector reached 1.23 billion US dollars [1]. In 1940, tannery industries to produce leather products were first established in Naranayganj close to Dhaka, later on it was shifted to Hazaribagh area of Dhaka. These tanneries are directly associated with the pollution of Buriganga river by discharging untreated toxic effluents contaminated with heavy metals. They discharged $12,000 \mathrm{~m}^{3}$ day $^{-1}$ untreated effluents in the Buriganga River which contains at least $30 \%$ to $40 \%$ of unused $\mathrm{Cr}$ [2]. Battery manufacturing companies and metal smelting industries near the Buriganga River dump their metallic residue and unusable batteries

\footnotetext{
$\triangle$ Md. Sazedul Islam, sazid.acce@du.ac.bd | ${ }^{1}$ Applied Chemistry and Chemical Engineering, University of Dhaka, Dhaka 1000, Bangladesh. ${ }^{2}$ Applied Chemistry and Chemical Engineering, Bangabandhu Shiekh Mujibur Rahman Science and Technology University, Goaplganj 8100, Bangladesh. ${ }^{3}$ Institute of Leather Engineering and Technology, University of Dhaka, Dhaka 1000, Bangladesh.
} 
in the river. These metallic residues contain heavy metals like $\mathrm{Pb}, \mathrm{Cd}, \mathrm{Zn}, \mathrm{Ni}$ etc. As a consequence of throwing and dumping of wastes and effluents containing various heavy metals in the river, not only river water but also the soil and vegetables of nearby area get polluted. Heavy metal pollution of soil and vegetables is one of the most severe ecological problems in the world as food chain contamination is the major pathway of heavy metal exposure for humans [3]. Metal uptake by food crops grown on such contaminated soils is high considering the high bio-availability of metal ions [4]. Metal transport from the river water to nearby agricultural land may be happened either by diffusion of metal ions from water to soil or by the overflow of the water to the bank of the river during rainy season. By overflow of the river water, cultivated lands are submerged and got toxic metal contamination [5]. Heavy metals in effluents penetrate into the soil during rainfall and are eventually accumulated into plants. After accumulation metals are translocated into various parts of the plants and through food chain manages to reach to human body [6]. Concentrations of the metals in different vegetables depend on soil composition, water, nutrient balance, as well as metal permissibility, selectivity and absorption ability of the vegetable species which varies from species to species [7]. Enrichment of trace metals in the vegetables is generally assessed by considering the metal levels in the soil in relation to the plant materials which is most commonly expressed as accumulation factor (AF) $[8,9]$. Not all the metals taken by plants are considered harmful for human, some metals present in vegetables play important role biochemically and physiologically from health point of view [10]. Metals like $\mathrm{Co}, \mathrm{Cr}(\mathrm{III}), \mathrm{Cu}, \mathrm{Fe}, \mathrm{Mn}$, and $\mathrm{Zn}$ help in regulating human metabolism [11, 12]. However, excessive content of metals beyond Maximum Permissible Level leads to number of nervous, cardiovascular, renal, neurological impairment as well as bone diseases and several other health disorders. Moreover, the presence of $\mathrm{Cd}$ and $\mathrm{Pb}$ in a very low concentration can cause various metabolic disorders resulting extremely serious consequences [13].

Several methods have so far been proposed by several researchers to estimate the potential health risks of pollutants [14]. One of the best methods for evaluating potential non-carcinogenic health risks associated with long-term exposure to chemical pollutants in foodstuff is the hazard quotient $(\mathrm{HQ})$ of the pollutants developed by USEPA $(2005)[15,16]$. HQ is the ratio between the estimated daily intake (EDI) of any pollutant and the oral reference dose $\left(R_{f} D\right)$ for it. According to Wang et al., if the $\mathrm{HI}$ (which is the total $\mathrm{HQ}$ ) value of two or more pollutants is $>1$, the consumers are already experiencing adverse health effects to some extent. On the other hand, carcinogenic health risk due to several metals may be calculated by target cancer risk (TCR) value [17].
In this research, the amount of various metals both essential ( $\mathrm{Ni}, \mathrm{Cu}$, and $\mathrm{Zn})$ and non-essential $(\mathrm{Cr}, \mathrm{Pb}$, and $\mathrm{Cd}$ ) present in locally cultivated six vegetables (Red amaranth (Amaranthus cruentus), Spinach (Spanacia oleracea), Jute leaf (Corchorus capsularies), Bottle Gourd (Lagenaria siceraria), Mustard green (Brassica juncea) and Water spinach (Impomoea aquatic) are determined. Health risk assessment for the consumers of those vegetables are estimated by using several types of parameter like EDI, $\mathrm{HQ}, \mathrm{HI}$ and TCR. The main objective of this study is to estimate noncarcinogenic and carcinogenic health risks of the consumers of locally grown vegetables in the Hazaribagh area, Dhaka, Bangladesh.

\section{Materials and methods}

\subsection{Sample collection}

For analysis, the samples were collected from the agricultural land beside the Buriganga River located Washpur, Hazaribagh, Dhaka which is about $1.5 \mathrm{~km}$ away from Rayer Bazar where untreated tannery effluent was directly discharged. These agricultural lands get immersed under water during rainy season and usually remain water logged for around 3 months. After water dries up from the land, vegetables cultivation starts.

Soil of six different locations near the Buriganga River was taken in a distance of 10-100 $\mathrm{m}$ range and the sites are labeled as S1, S2, S3, S4, S5 and S6 (shown in the map shown in Fig. 1). To evaluate the uptake and accumulation of various metals in vegetables, six different types of vegetables were collected from each of the six locations. These vegetables were given an identification number (ID) for the ease of the study and presented in Table 1 along with their local name and scientific name.

\subsection{Digestion of the soil samples}

Soil samples were digested for atomic absorption spectroscopic analysis (AAS) as described by McGrath et al. [18]. In brief, soil samples were grinded and passed through a $1 \mathrm{~mm}$ sieve to remove stones, roots and plant residues and then dried at $105^{\circ} \mathrm{C}$ for $8 \mathrm{~h}$ to remove moisture completely. $3 \mathrm{~g}$ of soil sample was weighted and taken into a glass test tube and then $8 \mathrm{ml}$ of conc. $\mathrm{HCl}(37 \%$ Merck, Germany) and $2 \mathrm{ml}$ of conc. $\mathrm{HNO}_{3}(69 \%$, Merck, Germany) was added. This mixture was then allowed to digest overnight at room temperature. Then reflux was done for $2 \mathrm{~h}$ at $120^{\circ} \mathrm{C}$ for complete digestion. After cooling, total volume of the content was made $50 \mathrm{ml}$ with deionized water. Then solution was filtered through Whatman no. 42 filter paper. 


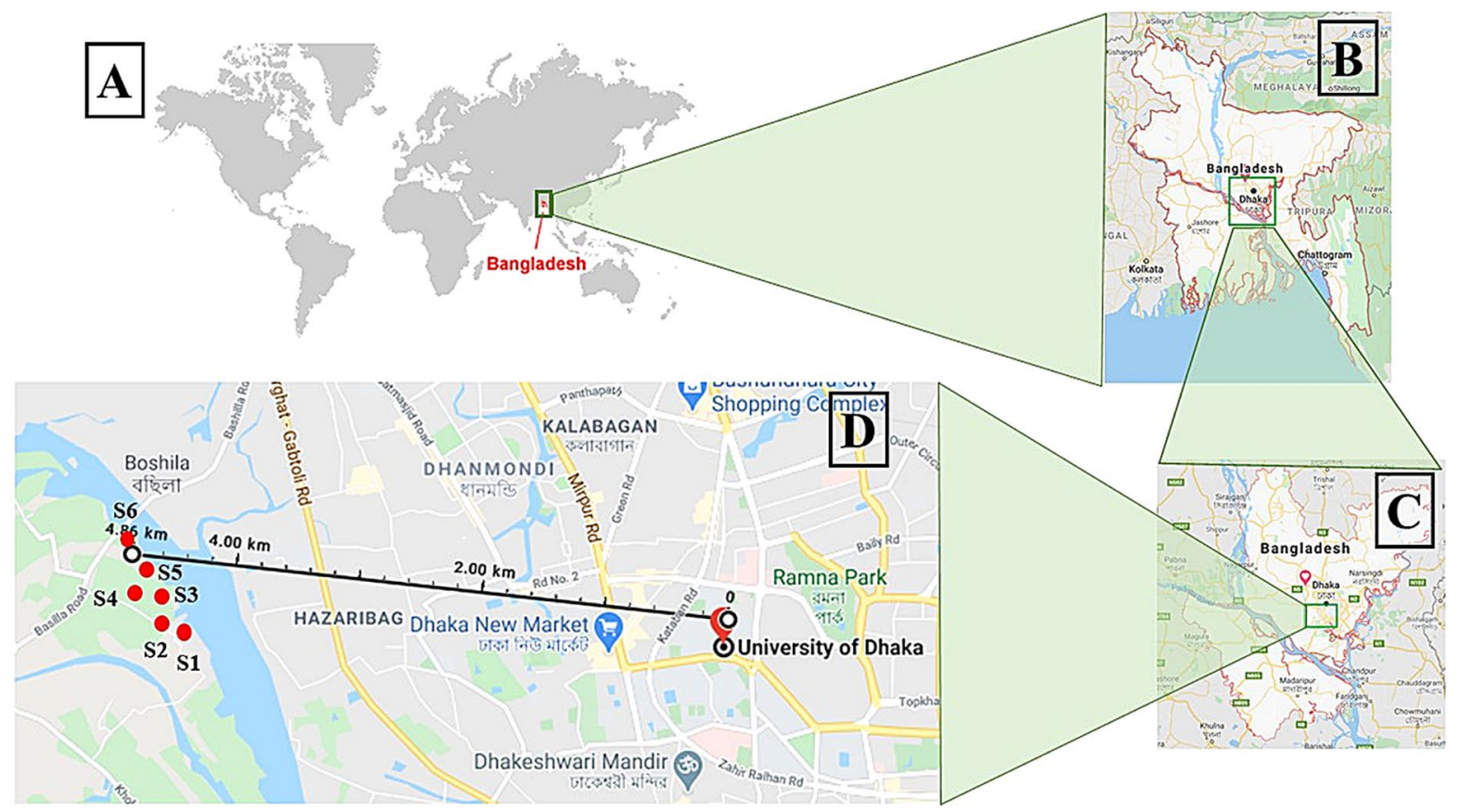

Fig.1 A World Map; B Map of Bangladesh with its capital Dhaka; C Map of capital Dhaka with marked central Dhaka; D Map of sampling area in Hazaribagh tannery which is situated $4.87 \mathrm{~km}$ from the University of Dhaka

Table 1 Local name, scientific name and ID of the sample vegetables grown in the vicinity of Hazaribagh industrial area

\begin{tabular}{lll}
\hline Local name & Scientific Name & Vegetable ID \\
\hline Red amaranth & Amaranthus cruentus & RA \\
Mustard green & Brassica juncea & $\mathrm{MG}$ \\
Jute & Corchorus capsularies & $\mathrm{Ju}$ \\
Water spinach & Impomoea aquatica & $\mathrm{WS}$ \\
Bottle gourd & Lagenaria siceraria & $\mathrm{BG}$ \\
Spinach & Spanacia oleracea & $\mathrm{Sp}$ \\
\hline
\end{tabular}

Each sample was digested in replicates of five and stored in polyethylene plastic bottles at $4^{\circ} \mathrm{C}$ till analysis $[19,20]$.

\subsection{Digestion of the vegetable samples}

Vegetable parts were digested in CEM microwave digester (MARS Xpress, USA; Model-907511) according to the manufacturer guideline. In brief, samples were cleaned with vinyl brush and cut into small pieces. The edible parts and roots of each vegetable samples were washed separately with distilled and deionized water to remove dirt and then samples were dried in a hot air oven at $70-80^{\circ} \mathrm{C}$ for $24 \mathrm{~h}$. The samples were then allowed to cool to room temperature in a desiccator, before further use. The size of the samples was again reduced below $0.4 \mathrm{~mm}$ by grinding to facilitate complete digestion.
About $0.5 \mathrm{~g}$ of each of the samples was transferred into a Teflon vessel and kept the vessel open for a minimum of $15 \mathrm{~min}$ for pre-digestion purpose. The vessels were then sealed and the samples were digested with $12 \mathrm{ml}$ of concentrated $\mathrm{HNO}_{3}$ acid (69\%, Merck, Germany) and $4 \mathrm{ml}$ of $\mathrm{H}_{2} \mathrm{O}_{2}\left(30 \%\right.$, Merck, Germany) at $200{ }^{\circ} \mathrm{C}$ in microwave digestion system. The Microwave digestion of the samples was conducted with a $1600 \mathrm{~W}$ power supply, temperature ranging from 180 to $220^{\circ} \mathrm{C}$, and holding time of $15 \mathrm{~min}$. After digestion, total volume of the content was made $50 \mathrm{ml}$ with deionized water. The digested samples were then filtered by using $0.45 \mu \mathrm{m}$ syringe filter (each samples were digested and analyzed for five times for the estimation of reproducibility test) and solutions were stored in $50 \mathrm{ml}$ polypropylene tubes at $4{ }^{\circ} \mathrm{C}$ till analysis [21].

\subsection{AAS analysis of the samples}

Concentration of the metals in the samples was measured by using a Perkin-Elmer flame atomic absorption spectrometer (Model-AAnalyst 800, USA) equipped with a deuterium lamp for background correction. For atomization, an air/acetylene flow at a fixed ratio was constantly maintained and concentrations of metals were measured by using specific hollow cathode lamp $(\mathrm{HCL})$ at a fixed wavelength. Blank samples of deionized water were accompanied after and before every run of analysis and five replicate samples were estimated. The wavelengths used for the determination of the metals 
were 228.8, 357.9, 324.8, 232.0, 283.3, and $213.9 \mathrm{~nm}$ for $\mathrm{Cd}$, $\mathrm{Cr}, \mathrm{Cu}, \mathrm{Ni}, \mathrm{Pb}$, and $\mathrm{Zn}$, respectively [20]. Results were summarized and represented in $\mathrm{mg} / \mathrm{kg}$ unit. Lower detection limit of flame AAS for $\mathrm{Cd}, \mathrm{Cr}, \mathrm{Cu}, \mathrm{Ni}, \mathrm{Pb}$, and $\mathrm{Zn}$ metals were 0.8 , 3.0, 1.5, 6.0, 15.0 and $1.5 \mu \mathrm{g} / \mathrm{l}$ respectively [22].

\subsection{Data analysis}

\subsubsection{Uptake, translocation, and accumulation of metals by the plants}

Biological concentration factor (BCF) was calculated from metal concentration ratio of plant roots to soil [23] according to Eq. 1. Translocation factor (TF) was evaluated from the ratio of heavy metals in plant's edible part to that in plant root as shown in Eq. 2 [24]. Biological accumulation factor (BAF) was calculated from the ratio of heavy metal in shoots to that in soil according to Eq. 3 [25]:

$B C F=\frac{C_{\text {root }}}{C_{\text {soil }}}$

$\mathrm{TF}=\frac{\mathrm{C}_{\text {edible part }}}{\mathrm{C}_{\text {root }}}$

$\mathrm{BAF}=\frac{\mathrm{C}_{\text {edible part }}}{\mathrm{C}_{\text {soil }}}$

where $C_{\text {edible part, }} C_{\text {root }}$ and $C_{\text {soil }}$ represent the heavy metal concentration in extracts of edible part and roots of the vegetable and soil samples on dry weight basis, respectively.

\subsubsection{Estimated daily intake (EDI) of metals}

The EDI of trace metals depends on metal concentrations (for dry weight basis), daily consumption rate and the average body weight of consumers. EDI for each metal can be determined by following formula [26].

$E D I=\frac{C_{m} \times I R \times E F \times E D}{B W \times A T}$

where $C_{m}=$ concentration of a metal in $\mathrm{mg} / \mathrm{kg}$; IR (ingestion rate) $=0.167 \mathrm{~kg} / \mathrm{day} ; \mathrm{EF}$ (exposure frequency) $=365$ day $/$ year; $E D$ (exposure duration) $=70$ year; BW (body weight) $=60 \mathrm{~kg}$; AT (average time for non-carcinogens) $=365 \times 70$ day.

\subsubsection{Health risk assessment}

In this study, the non-carcinogenic health risks associated with the consumption of the locally produced vegetables were assessed based on $\mathrm{HQ}$ of any metal and calculations were made using the following equation [27]. The unit of $\mathrm{R}_{\mathrm{f}} \mathrm{D}$ is $\mathrm{mg} \mathrm{kg}^{-1}$ day $^{-1}$.

$H Q=\frac{E D I}{R_{f} D}$

HI from HQs is expressed as the sum of the HQ of all the metals, which was determined by the following equation [28].

$\mathrm{HI}=\sum_{\mathrm{k}=1}^{\mathrm{n}} \mathrm{HQ}_{\mathrm{k}}$

where $\mathrm{HI}$ is the sum of more than one $\mathrm{HQ}$ for multiple substance or multiple pathways. If $\mathrm{HI}$ value is $<1$, that means there is not carcinogenic risk of consuming the vegetables on a regular basis and if $\mathrm{HI}$ value comes $>1$, that means there is a carcinogenic risk after intake of the metals in the measured quantity from the consumption of the vegetables.

The possibility of cancer risks through the intake of heavy metals due to consumption of the vegetables can be estimated by using the following equation

$\mathrm{CR}=\mathrm{EDI} \times \mathrm{CPS}$

where $C R$ represents the probability of individual lifetime health risks from carcinogens, unit of EDI is the $\mathrm{mg}$ $\mathrm{kg}^{-1}$ day $^{-1}$; CPS is the oral carcinogenic slope factor $(\mathrm{mg} / \mathrm{kg}$ day $)^{-1}$. Since CPS values were not available for all selected trace metals, so the $\mathrm{CR}$ of $\mathrm{Cr}, \mathrm{Ni}$, and $\mathrm{Pb}$, were calculated only to indicate the lifetime carcinogenic risk to the consumers. CPS value of $\mathrm{Cr}, \mathrm{Ni}$ and $\mathrm{Pb}$ are $5 \times 10^{-1}, 1.7$ and $8.5 \times 10^{-3}$ respectively [29].

The cumulative cancer risk was calculated by the following equation. The acceptable range of TCR is within the range of $\left(10^{-6}-10^{-4}\right)$, which means within this value there is no probability of carcinogenic attack after intake of specified metals [30].

Total cancer risk $(\mathrm{TCR})=\sum_{\mathrm{k}=1}^{\mathrm{n}} \mathrm{CR}_{\mathrm{k}}$

\section{Results and discussion}

\subsection{Trace metals concentration in soil}

The concentration of each metal in different soil samples has been summarized along with the Dutch standard of soil in Table 2. The concentrations of metals in the present study were compared with the Dutch soil quality guidelines as no guideline values were established for trace 
metals in the soil of Bangladesh. $\mathrm{Cr}$ and $\mathrm{Pb}$ were found to be present in higher quantity in the soil samples as compared to their standard values. $\mathrm{Cr}$ and $\mathrm{Pb}$ concentrations were observed almost five and two times higher than their standard values, respectively. There were more than 200 tannery industries near the agricultural field, which use chrome salts for tanning. In tanning process, excess chrome salts are usually used for complete crosslinking of collagen in the skin of animals. The untreated effluent of this process and trimmed wastes of $\mathrm{Cr}$ tanned leather result in rising of $\mathrm{Cr}$ content in the soil after being thrown in the nearby environment. Battery manufacturing and $\mathrm{Pb}$ smelting industries in this area dump non-usable and rejected battery wastes in nearby locality and these wastes probably release $\mathrm{Pb}$ in the environment slowly. Concentrations of $\mathrm{Ni}$ and $\mathrm{Cu}$ were slightly higher and $\mathrm{Zn}$ content was slightly lower in the sample soils than their standard values as specified in the Dutch soil standard, which may be due to the establishment of many metal processing industries in that area. The variation of different heavy metals in different sample locations may be due to the capability of mobility of these metal ions.

\subsection{Trace metals concentration in the local vegetables produce}

Phytostabilization, rhizofiltration, phytoaccumulation, and phytovolatilization are the mechanisms responsible for uptake, translocation and accumulation of metal ions in any plan $[4,21]$. Metal ions uptake by a plant depends on various factors such as chelating agents produced in plant roots, $\mathrm{pH}$ change induced by plants and redox reaction [31]. The estimated value of metal ions concentration in root and edible parts of various plants has been illustrated in Fig. 2. Total concentration of metal ions present in RA, MG, Ju, WS, BG and Sp were calculated 68.44, 78.90, 66.65, $69.33,68.32$ and $54.60 \mathrm{mg} / \mathrm{kg}$, respectively. Total metal concentration was found highest in case of MG and the lowest for Sp. It may be due to the fact that MG belongs to Brassica family and act as hyper-accumulator [32]. The concentration of different heavy metal varies from plant to plant, due to their different accumulation abilities, properties of medium, environmental condition, bioavailability of the metal, root zone and various soil properties $[28,31]$.

The total amount of essential plant micronutrients (summation of the concentration of $\mathrm{Cu}, \mathrm{Ni}$, and $\mathrm{Zn}$ ) are found higher in RA (12 mg/kg), BG (1 mg/ $\mathrm{kg})$ and Ju $(26 \mathrm{mg} / \mathrm{kg}$ ) than in other plants. Among the non-essential metals, $\mathrm{Pb}$ was found the highest in BG and lowest in $\mathrm{Sp}$; $\mathrm{Cd}$ was found highest in $\mathrm{Sp}$ and lowest in WS; and $\mathrm{Cr}$ was found highest in WS and lowest in Sp.

Cr was found to be accumulated the highest in concentration in all plants than any other metals ranging from $54 \mathrm{mg} / \mathrm{kg}$ for WS to $25 \mathrm{mg} / \mathrm{kg}$ for Sp which is definitely due to the highest bioavailability of $\mathrm{Cr}$ in soil compared to other metals [31,33]. Among all metals, only $\mathrm{Pb}$ and $\mathrm{Cr}$ content in vegetables crossed the safety limit set by FAO/WHO and Chinese Ministry of Health (CMH) [34, 35]. $\mathrm{Pb}$ content in soils was found in high quantities with an average of $197 \mathrm{mg} / \mathrm{Kg}$, which catalyzed the high bioaccumulation of $\mathrm{Pb}$ due to rapid uptake capacity from soil to plant's root and root to edible parts. This is probably because plants can solubilize and take up $\mathrm{Pb}$ from its partially insoluble form from the soil [31].

From the data of the various metal ion concentrations in different parts of the vegetables, BCF, TF and BAF of the sample vegetables were calculated according to Eqs. 1, 2, and 3 , respectively and their values have been presented in Table 3.

The highest BCF was found for $\mathrm{Cu}$ in RA. The total BCF was also found higher in RA compared to any other plants, which indicates that RA has higher tendency towards metal precipitation on root than others which might be due to its massive fibrous root system [36]. BCF of nonessential metals $(\mathrm{Cr}, \mathrm{Cd}$ and $\mathrm{Pb})$ were observed higher in $\mathrm{Sp}, \mathrm{MG}$, and RA compared to those of other vegetables.

A key trait of metal hyperaccumulators is the efficient metal transport from roots to edible parts, characterized by the TF being $>1$ [37]. Plant's essential metals like $\mathrm{Cu}, \mathrm{Ni}$ and $\mathrm{Zn}$ showed TF $>1$ for most of the plant species. For $\mathrm{Cu}$, TF was $>1$ in RA, MG and $\mathrm{Sp}$ while for $\mathrm{Ni}$, TF was $>1$ in MG, WS, BG and for Zn TF was > 1 in RA, Ju, WS, BG. The

Table 2 Concentration of trace metals in soil samples $(\mathrm{mg} / \mathrm{kg})$

\begin{tabular}{lllllll}
\hline Sample ID & $\mathrm{Cr}$ & $\mathrm{Ni}$ & $\mathrm{Cu}$ & $\mathrm{Zn}$ & $\mathrm{Cd}$ & $\mathrm{Pb}$ \\
\hline S1 & 491 & 36.60 & 37.21 & 26.71 & 0.56 & 131.89 \\
S2 & 455 & 57.41 & 54.21 & 52.42 & 0.91 & 169.12 \\
S3 & 561 & 55.97 & 46.32 & 38.38 & 0.85 & 299.55 \\
S4 & 501 & 48.07 & 44.53 & 36.24 & 0.82 & 210.96 \\
S5 & 525 & 57.92 & 50.93 & 35.14 & 0.47 & 194.81 \\
S6 & 537 & 65.46 & 57.45 & 44.25 & 0.92 & 177.20 \\
Mean concentration & $512 \pm 37$ & $54 \pm 10$ & $48 \pm 7$ & $39 \pm 9$ & $0.8 \pm 0.2$ & $197 \pm 57$ \\
Dutch standard & 100 & 35 & 36 & 140 & 0.8 & 85 \\
\hline
\end{tabular}



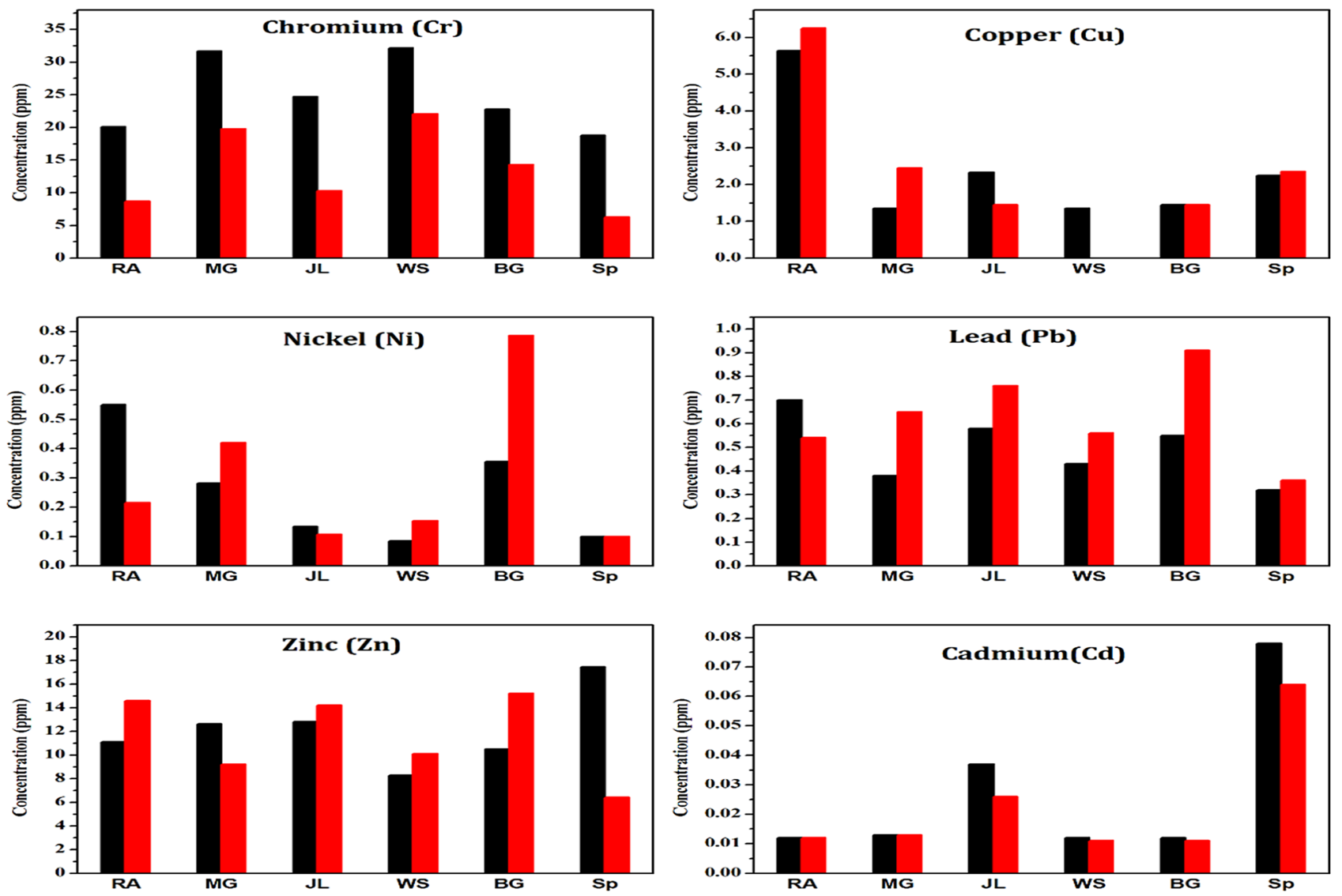

Root

Edible parts

Fig. 2 Estimated concentrations of different metals in various parts of the vegetables collected from the sampling area

Table 3 BCF, TF and BAF values of different metals in the sample vegetables

\begin{tabular}{llllllll}
\hline Plants & Parameter & $\mathrm{Cr}$ & $\mathrm{Ni}$ & $\mathrm{Cu}$ & $\mathrm{Zn}$ & $\mathrm{Cd}$ & $\mathrm{Pb}$ \\
\hline $\mathrm{RA}$ & $\mathrm{BCF}$ & 0.04 & 0.02 & 0.15 & 0.08 & 0.02 & 0.03 \\
& TF & 0.43 & 0.39 & 1.11 & 1.32 & 1.00 & 0.77 \\
$\mathrm{NG}$ & $\mathrm{BAF}$ & 0.02 & 0.01 & 0.17 & 0.11 & 0.02 & 0.02 \\
& BCF & 0.07 & 0.01 & 0.03 & 0.08 & 0.01 & 0.01 \\
& TF & 0.63 & 1.49 & 1.82 & 0.73 & 1.00 & 1.71 \\
Ju & BAF & 0.04 & 0.01 & 0.05 & 0.05 & 0.01 & 0.01 \\
& BCF & 0.04 & 0.00 & 0.05 & 0.04 & 0.04 & 0.02 \\
& TF & 0.42 & 0.80 & 0.62 & 1.11 & 0.70 & 1.31 \\
WS & BAF & 0.02 & 0.00 & 0.03 & 0.05 & 0.03 & 0.02 \\
& BCF & 0.06 & 0.00 & 0.03 & 0.01 & 0.02 & 0.01 \\
& TF & 0.69 & 1.81 & 0.00 & 1.22 & 0.92 & 1.30 \\
BG & BAF & 0.04 & 0.00 & 0.00 & 0.05 & 0.01 & 0.02 \\
& BCF & 0.04 & 0.01 & 0.03 & 0.05 & 0.03 & 0.02 \\
& TF & 0.63 & 2.21 & 1.00 & 1.45 & 0.92 & 1.66 \\
Sp & BAF & 0.03 & 0.01 & 0.03 & 0.08 & 0.02 & 0.03 \\
& BCF & 0.04 & 0.00 & 0.04 & 0.10 & 0.09 & 0.01 \\
& TF & 0.34 & 1.00 & 1.04 & 0.37 & 0.82 & 1.13 \\
& BAF & 0.01 & 0.00 & 0.04 & 0.04 & 0.07 & 0.01 \\
\hline
\end{tabular}


higher uptake of essential metals in vegetables may be due to higher transpiration rate to maintain the growth and moisture content of these plants. In literature, TF value for only WS (0.30-5.40) and Sp (0.17-0.89) are available, of them TF value of all metals are found below 1 except $\mathrm{Cu}$ in WS (5.40).

Among plant's non-essential metal ions, $\mathrm{Cr}$ showed the lowest affinity to translocate from root to edible parts. It might be due to the phytostabilization of the plants which renders the translocation of metal ions and demobilize them in the roots [38]. Cd showed TF of equal or $<1$ in all cases. It affirmed that $\mathrm{Cd}$ was not translocated to the edible parts as great as $\mathrm{Pb}$ which may be due to its low concentration in roots.

In this study, $\mathrm{Pb}$ showed TF $<1$ only for RA. RA belongs to Amaranthaceae family, so it has comparatively high lead in its root than other parts due to massive fibrous root system which provides large surface area to accumulate lead in the root and it also prevent translocation of $\mathrm{Pb}$ in the edible parts. TF value for $\mathrm{Pb}$ for other plants is found $>1$ suggesting the effective translocation of $\mathrm{Pb}$ from the roots to the shoots [39].

BAF represents the tendency of the plant to accumulate metal in the consuming part of it. Depending on this value plants can be hyperaccumulator $(B A F>1)$ or excluder (BAF $<1)$. In this study, BAF was found $<1$ for all metals in all plants which suggested that these plants only absorbed heavy metals but did not accumulate them (excluders). BG showed the highest BAF values for $\mathrm{Ni}$ and $\mathrm{Pb}$ while RA showed the highest BAF for $\mathrm{Cu}$ and $\mathrm{Zn}$. BAF of $\mathrm{Cr}$ and $\mathrm{Cd}$ were found greater in WS and Sp. When compared with other studies as shown in Table 4, a lower BAF value is observed which can be attributed to difference in location, soil properties (concentration of metals in soil, $\mathrm{pH}$, organic matter, clay content, cation exchange capacity, metals forms or speciation in soils), vegetable tissue uptake efficiency and growth factors.

Various factors may influence heavy metal solubility and as a consequence the availability for plants [46]. $\mathrm{Cr}$ in the soil present in various oxidation states, among them $\mathrm{Cr}(\mathrm{VI})$ is highly soluble and more toxic. BCF for total $\mathrm{Cr}$ in each of the plants studied is $<1$, that means that $\mathrm{Cr}$ uptake from the soil is not very high though in Table 2. It was observed that the concentration of $\mathrm{Cr}$ is the highest among all the metals tested in all soil samples in this study. TF for $\mathrm{Cr}$ was obtained the lowest (0.4-0.6) among all the metals studied. According to Valerie. et al. [47], $\mathrm{Cr}$ can retain in the roots due to insolubilization (e.g., at the root surface and in the root apoplast) or to a compartmentation in cells avoiding the release to the xylem. The BAF value for $\mathrm{Cr}$ was also obtained quite low (0.02-0.04).

TF values obtained for $\mathrm{Ni}(0.39-2.2), \mathrm{Zn}(0.7-1.4)$ were little higher than for $\mathrm{Cd}(0.7-1)$. The symplastic transport via the phloem allows a redistribution of nutrients, assimilates and pollutants within the plants. $\mathrm{Ni}$ and $\mathrm{Zn}$ are highly phloem-mobile and can be redistributed in crop plants throughout vegetative growth and the reproductive phase [47]. Cd is less phloem-mobile than $\mathrm{Zn}$, but it is also to some extent redistributed via the phloem [47]. BAF values for $\mathrm{Ni}(0-0.01), \mathrm{Zn}(0.05-0.1)$ and $\mathrm{Cd}(0.01-0.07)$ are observed quite low, this may be due to the redistribution of the metals from senescing leaves via the phloem to growing vegetative parts and maturing fruits.

TF value (0-1.8) and BAF value (0-0.17) obtained for $\mathrm{Cu}$ were like those for $\mathrm{Ni}, \mathrm{Zn}$ and $\mathrm{Cd}$. It is reported that Cu form metal complex with nicotianamine and was proposed to be important for the translocation of $\mathrm{Cu}$ from leaves to developing organs and maturing seeds $[48,49]$. It is also reported that metallothioneins such as cysteinerich proteins in plants have high affinity for binding metal cations such as $\mathrm{Cd}, \mathrm{Cu}$ and $\mathrm{Zn}$ [50].

$\mathrm{BCF}$ values obtained for $\mathrm{Pb}$ is in the range of $(0.01-0.03)$ which means a small portion of $\mathrm{Pb}$ from the soil is probably taken up by the plants. However, the TF value (0.7-1.6) is high that represents the translocation of $\mathrm{Pb}$ from root to shoot/leaves of the plants studied. Though the TF value and $\mathrm{BAF}$ value $(0.01-0.03)$ obtained for $\mathrm{Pb}$ were close to the those values determined in this study for other metals except $\mathrm{Cr}$, the mechanism of $\mathrm{Pb}$ uptake and translocation within plants is different from others'. Dan et al. [51] suggested that lignifications of cell wall and formation of metal-lignin complex might be one of the primary mechanisms of Pb tolerance in the roots of scented Geranium plant. Sekara et al. studied $\mathrm{Pb}$ contamination of nine crops and found the highest deposition of lead in leaves than in its' roots of all plants other than barley and maize [52].

\subsection{Health risk assessment}

\subsubsection{Hazard quotient estimation}

Health risks of the residents in the study area, through consumption of these vegetables, were evaluated by $\mathrm{HQ}$ obtained by estimating EDI using Eqs. 4 and 5 . Table 5 represents the EDI values of the metals studied and their $R_{f} D$ values. The $R_{f} D$ values were obtained from Integrated Risk Information Systems [53]. EDI values of $\mathrm{Pb}$ was obtained above or very close to the $R_{f} D$ value in case of all plants except Spinach. However, it was noticed that EDI values of most of the metals were obtained below the $R_{f} D$ values.

$\mathrm{HQ}$ values of each metal were calculated according to Eq. 4 and their value has been summarized in Table 6. HQ values of most of the metals were found $<1$ except that of $\mathrm{Pb}$ in case of $\mathrm{RA}, \mathrm{Ju}$, and $\mathrm{BG}$. $\mathrm{HI}$ values were derived from $H Q$. HI values of RA, Ju, BG, Sp, MG, and WS were obtained 
Table 4 Comparison of the obtained BCF and TF values in this study with that obtained for the studied metals and plants in other studies

\begin{tabular}{|c|c|c|c|c|c|c|}
\hline \multirow[t]{2}{*}{ Sample ID } & \multirow[t]{2}{*}{ Element } & \multicolumn{2}{|c|}{$\begin{array}{l}\text { TF and BAF values } \\
\text { obtained in this study }\end{array}$} & \multicolumn{2}{|c|}{$\begin{array}{l}\text { TF and BAF values found in } \\
\text { literature }\end{array}$} & \multirow[t]{2}{*}{ Reference } \\
\hline & & TF & BAF & TF & BAF & \\
\hline \multirow[t]{6}{*}{ RA } & $\mathrm{Cr}$ & 0.43 & 0.02 & - & 0.02 & {$[40]$} \\
\hline & $\mathrm{Ni}$ & 0.39 & 0.01 & - & - & \\
\hline & $\mathrm{Cu}$ & 1.11 & 0.17 & - & 0.09 & \\
\hline & $\mathrm{Zn}$ & 1.32 & 0.11 & - & 0.57 & \\
\hline & $\mathrm{Cd}$ & 1.00 & 0.02 & - & 1.16 & \\
\hline & $\mathrm{Pb}$ & 0.77 & 0.02 & - & 0.06 & \\
\hline \multirow[t]{6}{*}{ MG } & $\mathrm{Cr}$ & 0.63 & 0.04 & - & 0.794 & [41] \\
\hline & $\mathrm{Ni}$ & 1.49 & 0.01 & - & 11.668 & \\
\hline & $\mathrm{Cu}$ & 1.82 & 0.05 & - & 0.208 & \\
\hline & $\mathrm{Zn}$ & 0.73 & 0.05 & - & 0.195 & \\
\hline & $\mathrm{Cd}$ & 1.00 & 0.01 & - & 0.435 & \\
\hline & $\mathrm{Pb}$ & 1.71 & 0.01 & - & 0.436 & \\
\hline \multirow[t]{6}{*}{$\mathrm{Ju}$} & $\mathrm{Cr}$ & 0.42 & 0.02 & - & 0.83 & {$[42]$} \\
\hline & $\mathrm{Ni}$ & 0.80 & $\mathrm{BDL}$ & - & 0.24 & \\
\hline & $\mathrm{Cu}$ & 0.62 & 0.03 & - & 1.45 & \\
\hline & $\mathrm{Zn}$ & 1.11 & 0.05 & - & 2.68 & \\
\hline & $\mathrm{Cd}$ & 0.70 & 0.01 & - & - & \\
\hline & $\mathrm{Pb}$ & 1.31 & 0.02 & - & 0.45 & \\
\hline \multirow[t]{6}{*}{ WS } & $\mathrm{Cr}$ & 0.69 & 0.04 & - & - & [43] \\
\hline & $\mathrm{Ni}$ & 1.81 & $\mathrm{BDL}$ & 0.60 & 1.80 & \\
\hline & $\mathrm{Cu}$ & $\mathrm{BDL}$ & $\mathrm{BDL}$ & 5.40 & $\mathrm{BDL}$ & \\
\hline & $\mathrm{Zn}$ & 1.22 & 0.05 & 0.30 & 11.90 & \\
\hline & $\mathrm{Cd}$ & 0.92 & 0.01 & 0.50 & 1.00 & \\
\hline & $\mathrm{Pb}$ & 1.30 & 0.02 & - & - & \\
\hline \multirow[t]{6}{*}{ BG } & $\mathrm{Cr}$ & 0.63 & 0.03 & - & 2.00 & [44] \\
\hline & $\mathrm{Ni}$ & 2.21 & 0.01 & - & 3.50 & \\
\hline & $\mathrm{Cu}$ & 1.00 & 0.03 & - & 0.29 & \\
\hline & $\mathrm{Zn}$ & 1.45 & 0.08 & - & 0.67 & \\
\hline & $\mathrm{Cd}$ & 0.92 & 0.02 & - & 1.41 & \\
\hline & $\mathrm{Pb}$ & 1.66 & 0.03 & - & 11.48 & \\
\hline \multirow[t]{6}{*}{ Sp } & $\mathrm{Cr}$ & 0.34 & 0.01 & 0.40 & 0.03 & [45] \\
\hline & $\mathrm{Ni}$ & 1.00 & 0.00 & 0.45 & 0.06 & \\
\hline & $\mathrm{Cu}$ & 1.04 & 0.04 & 0.51 & 0.35 & \\
\hline & $\mathrm{Zn}$ & 0.37 & 0.04 & 0.89 & 0.43 & \\
\hline & $\mathrm{Cd}$ & 0.82 & 0.07 & 0.65 & 0.27 & \\
\hline & $\mathrm{Pb}$ & 1.13 & 0.01 & 0.17 & BDL & \\
\hline
\end{tabular}

$B D L$ below detection limit

$2.53,2.18,2.11,2.1,1.75$ and 1.36, respectively. According to Lemly [54], HI = (1-10) refers to moderate hazard. In an independent study in a mining area of China [55] and in a $\mathrm{Cu}$ and Ni mine and smelter area in Botswana of Africa [25], $\mathrm{HI}$ were found 2.1 and 2.89 , respectively. The results of $\mathrm{HI}$ values in this study obtained in the range of (1.36-2.53), which was noticed to be as hazardous as mentioned in the above mining area. HI found in this current study suggested that a significant effect will be found for longtime exposure in near future.

\subsection{Cancer risk assessment}

International Agency for Research on Cancer (IARC) classified $\mathrm{Ni}, \mathrm{Cr}$, and $\mathrm{Pb}$ as predominant contaminants to be potential carcinogenic element [57]. The exposure of the people in the studied area to $\mathrm{Cr}$, Ni and $\mathrm{Pb}$ contamination after daily consumption of the locally grown vegetables may be health hazardous to them. This is why, the probability of an individual for lifetime health risks from carcinogens (CR) and total cancer risk (TCR) were calculated 
according to Eqs. 7 and 8, respectively and the results were summarized in Table 7.

The $\mathrm{CR}$ values of $\mathrm{Cr}$ and $\mathrm{Ni}$ were found to be lower than the hazardous limit whereas that of the $\mathrm{Pb}$ was found higher in RA, Ju and BG than the reference limit. $T C R$ was calculated from the $C R$ values and it was found the highest of $3387 \times 10^{-4}$ for BG and the lowest of $811 \times 10^{-4}$ for $\mathrm{Sp}$. The calculated risk values indicated that the consumption of bottle gourd, mustard green, red spinach, water spinach, jute leaves and spinach would result in an excess of 3387, 2380, 2329, 1225, 1067 and 811 cancer cases per 10,000 people, respectively. USEPA considers excess cancer risks that are below about 1 chance in $1,000,000\left(1 \times 10^{-6}\right)$ to be so small as to be negligible, and risks above 1 in $10,000\left(1 \times 10^{-4}\right)$ to be sufficiently large that some sort of remediation is desirable
[58]. TCR $>1$ in ten thousand $\left(T C R>10^{-4}\right)$ is benchmark for gathering additional information whereas one in one thousand $\left(\mathrm{TCR}>10^{-3}\right.$ ) is moderately increased risk and should be given high priority as a public health concern [59]. In this study, all the plants have resulted in a value of TCR $>10^{-3}$, which would cause moderately increased risk of cancer. Chronic exposure to low doses of $\mathrm{Ni}$ and $\mathrm{Pb}$ could, therefore, may result in many types of cancers [60]. Though the risk assessment of $\mathrm{Cr}$ estimated from the sampling data was observed less than the specified value of USEPA, it is worthy to be mentioned that the toxicity of chromium depends on its chemical form. $\mathrm{Cr}$ (VI) compounds having a toxic, mutagenic and even carcinogenic nature, however, $\mathrm{Cr}$ (III) which prevails in foodstuffs has no associated toxicity [61].
Table $5 R_{f} D$ values and estimated EDI values of different heavy metals through consumption of the sample vegetables

\begin{tabular}{|c|c|c|c|c|c|c|c|}
\hline \multirow{4}{*}{$\begin{array}{l}\text { Species } \\
\mathrm{R}_{\mathrm{f}} \mathrm{D}[13,29,56] \\
\left(\mathrm{mg} \mathrm{kg}^{-1} \text { day }^{-1}\right)\end{array}$} & \multicolumn{6}{|c|}{ Elements } & \multirow[t]{4}{*}{ Total ED } \\
\hline & $\mathrm{Cr}$ & $\mathrm{Ni}$ & $\mathrm{Cu}$ & $\mathrm{Zn}$ & $\mathrm{Cd}$ & $\mathrm{Pb}$ & \\
\hline & \multicolumn{6}{|c|}{$\mathrm{EDI}\left(\mathrm{mg} \mathrm{kg}^{-1} \mathrm{day}^{-1}\right)$} & \\
\hline & 1.50 & 0.02 & 0.040 & 0.30 & 0.0005 & 0.003 & \\
\hline RA & 0.09 & 0.0023 & 0.036 & 0.08 & 0.0001 & 0.004 & 0.21 \\
\hline MG & 0.15 & 0.0021 & 0.011 & 0.07 & 0.0001 & 0.003 & 0.24 \\
\hline Ju & 0.11 & 0.0007 & 0.011 & 0.08 & 0.0002 & 0.004 & 0.2 \\
\hline WS & 0.16 & 0.0007 & 0.004 & 0.04 & 0.0001 & 0.003 & 0.21 \\
\hline BG & 0.11 & 0.0034 & 0.009 & 0.08 & 0.0001 & 0.004 & 0.21 \\
\hline Sp & 0.08 & 0.0006 & 0.014 & 0.07 & 0.0004 & 0.002 & 0.16 \\
\hline
\end{tabular}

\begin{tabular}{|c|c|c|c|c|c|c|c|}
\hline \multirow[t]{3}{*}{ Species } & \multicolumn{6}{|c|}{ Elements } & \multirow[t]{3}{*}{$\mathrm{HI}$} \\
\hline & $\mathrm{Cr}$ & $\mathrm{Ni}$ & $\mathrm{Cu}$ & $\mathrm{Zn}$ & $\mathrm{Cd}$ & $\mathrm{Pb}$ & \\
\hline & \multicolumn{6}{|l|}{$\mathrm{HQ}$} & \\
\hline RA & 0.06 & 0.11 & 0.890 & 0.26 & 0.14 & 1.060 & 2.53 \\
\hline MG & 0.10 & 0.11 & 0.290 & 0.22 & 0.16 & 0.880 & 1.75 \\
\hline $\mathrm{Ju}$ & 0.07 & 0.04 & 0.280 & 0.26 & 0.38 & 1.150 & 2.18 \\
\hline WS & 0.11 & 0.04 & 0.100 & 0.12 & 0.14 & 0.850 & 1.36 \\
\hline BG & 0.07 & 0.17 & 0.220 & 0.26 & 0.14 & 1.250 & 2.11 \\
\hline $\mathrm{Sp}$ & 0.05 & 0.03 & 0.350 & 0.24 & 0.85 & 0.580 & 2.1 \\
\hline
\end{tabular}

Table 7 CR and TCR values of the consumer of the locally produced vegetables from the study area in Bangladesh
Table 6 Calculated HQ and $\mathrm{HI}$ values of different heavy of the vegetable's samples metals through consumption

\begin{tabular}{lllrlrrr}
\hline Element & CPS $(\mathrm{mg} / \mathrm{kg} . \text { day })^{-1}$ & \multicolumn{6}{l}{ CR values $\left(\times 10^{-4}\right)$} \\
\cline { 3 - 7 } & & RA & MG & Ju & WS & BG & Sp \\
\hline $\mathrm{Cr}$ & $5 \times 10^{-1}$ & 288 & 515 & 350 & 543 & 371 & 251 \\
$\mathrm{Ni}$ & 1.7 & 1951 & 1790 & 620 & 609 & 2910 & 510 \\
$\mathrm{~Pb}$ & $8.5 \times 10^{-3}$ & 90.3 & 75 & 97.6 & 72.1 & 106 & 49.5 \\
$\mathrm{TCR}$ & & 2329 & 2380 & 1067 & 1225 & 3387 & 811 \\
\hline
\end{tabular}




\section{Conclusion}

Metal contamination in soil is gaining increasing attention all over the world. Principally, there are two major pathways for human exposure to soil contamination, one is soil-plant-human (food chain pathway) and another one is soil-human (incidental soil ingestion). The present study focused on food chain pathway. From the present investigation, it is clear that the agricultural land near Hazaribagh is already contaminated by heavy metals. Chromium and lead content exceed the FAO/WHO recommended permissible limits in vegetables. $\mathrm{HQ}$ for individual metal was below 1 in most of the cases, suggesting that people would not experience significant health hazards if they ingest a single metal from vegetables, but cumulative effect as shown by $\mathrm{HI}$ value was found $>1$ for all the vegetables tested. It indicates that people would experience noncarcinogenic health risks due to consumption of them. The carcinogenic risks of $\mathrm{Cr}, \mathrm{Ni}$, and $\mathrm{Pb}$ through consumption of the vegetables were obtained higher than the USEPA threshold level $\left(1 \times 10^{-6}\right)$, indicating potential cancer risks. This suggests that more attention should be given particularly to $\mathrm{Cr}, \mathrm{Ni}$, and $\mathrm{Pb}$ levels in the soil to assure food safety to local consumers and to protect them from serious lifetime health risks.

Acknowledgements The authors acknowledge their affiliated institutions.

\section{Compliance with ethical standards}

Conflict of interest The authors declare they have no conflict of interest.

\section{References}

1. Tinni SH, Islam MA, Fatima K, Ali MA (2014) Impact of tanneries waste disposal on environment in some selected areas of dhaka city corporation. J Environ Sci Nat Resour 7:149-156

2. Biswas B, Hamada T (2012) Relation between Hazaribagh tannery industry development and buriganga river pollution in Bangladesh. Int J Environ 2:117-127

3. Miclean M, Cadar O, Levei L, Senila L, Ozunu A (2018) Metal contents and potential health risk assessment of crops grown in a former mining district (Romania). J Environ Sci Health Part B 53:595-601

4. Chen Y, Wang C, Wang Z (2005) Residues and source identification of persistent organic pollutants in farmland soils irrigated by effluents from biological treatment plants. Environ Int 31:778-783

5. Jolly YN, Choudhury TR, Islam A, Suravi NI, Sultana MS (2012) Background chemical study of relocated hazaribagh tannery complex environment, Savar. J Bangladesh Acad Sci 36:45-51

6. Ideriah TJK, Harry FO, Stanley HO, Igbara JK (2010) Heavy metal contamination of soils and vegetation around solid waste dumps in Port Harcourt, Nigeria. J Appl Sci Environ Manag 14:101-109

7. Ahmad JU, Goni MA (2010) Heavy metal contamination in water, soil, and vegetables of the industrial areas in Dhaka, Bangladesh. Environ Monit Assess 166:347-357

8. Khan S, Rehman S, Khan AZ, Khan MA, Shah MT (2010) Soil and vegetables enrichment with heavy metals from geological sources in Gilgit, northern Pakistan. Ecotoxicol Environ Saf 73:1820-1827

9. Li Q, Chen Y, Fu H, Cui Z, Shi L, Wang L, Liu Z (2012) Health risk of heavy metals in food crops grown on reclaimed tidal flat soil in the pearl river Estuary, China. J Hazard Mater 227:148-154

10. Maleki A, Zarasvand MA (2008) Heavy metals in selected edible vegetables and estimation of their daily intake in Sanandaj, Iran. SE Asian J Trop Med Public Health 39:335-340

11. Lokeshappa B, Shivpuri K, Tripathi V, Dikshit AK (2012) Assessment of toxic metals in agricultural produce. Food Public Health 2:24-29

12. Duruibe JO, Ogwuegbu M, Egwurugwu J (2007) Heavy metal pollution and human biotoxic effects. Int J Phys Sci 2:112-118

13. Khan S, Cao Q, Zheng YM, Huang YZ, Zhu YG (2008) Health risks of heavy metals in contaminated soils and food crops irrigated with wastewater in Beijing, China. Environ Pollut 152:686-692

14. Miclean M, Cadar O, Levei EA, Roman R, Ozunu A, Levei L (2019) Metal (pb, cu, cd, and zn) transfer along food chain and health risk assessment through raw milk consumption from free-range cows. Int J Environ Res Public Health 16:1-14

15. USEPA (2005) Region 6, Human Health Risk Assessment Protocol, Chapter 7: Characterizing Risk and Hazard, Multimedia Planning and Permitting Division. Office of Solid Waste, Center for Combustion Science and Engineering

16. Chien L-C, Hung T-C, Choang K-Y, Yeh C-Y, Meng P-J, Shieh M-J, Han B-C (2002) Daily intake of tbt, cu, zn, cd and as for fishermen in Taiwan. Sci Total Environ 285:177-185

17. Wang X, Sato T, Xing B, Tao S (2005) Health risks of heavy metals to the general public in Tianjin, China via consumption of vegetables and fish. Sci Total Environ 350:28-37

18. McGrath SP, Cunliffe CH (1985) A simplified method for the extraction of the metals $\mathrm{Fe}, \mathrm{Zn}, \mathrm{Cu}, \mathrm{Ni}, \mathrm{Cd}, \mathrm{Pb}, \mathrm{Cr}, \mathrm{Co}$ and $\mathrm{Mn}$ from soils and sewage sludges. J Sci Food Agric 36:794-798

19. Sastre J, Sahuquillo A, Vidal M, Rauret G (2002) Determination of $\mathrm{Cd}, \mathrm{Cu}, \mathrm{Pb}$ and $\mathrm{Zn}$ in environmental samples: microwaveassisted total digestion versus aqua regia and nitric acid extraction. Anal Chim Acta 462:59-72

20. Tüzen M (2003) Determination of heavy metals in soil, mushroom and plant samples by atomic absorption spectrometry. Microchem J 74:289-297

21. Islam MS, Hoque MF (2014) Concentrations of heavy metals in vegetables around the industrial area of Dhaka city, Bangladesh and health risk assessment. Int Food Res J 21:2121-2126

22. The Perkin-Elmer Corporation (1996) Analytical Methods for Atomic Absorption Spectroscopy. Manual Part No. 0303-0152, Release D. Waltham MA: The Perkin-Elmer Co.

23. Yoon J, Cao X, Zhou Q, Ma LQ (2006) Accumulation of Pb, Cu, and $\mathrm{Zn}$ in native plants growing on a contaminated Florida site. Sci Total Environ 368:456-464

24. Cui S, Zhou Q, Chao L (2007) Potential hyperaccumulation of Pb, $\mathrm{Zn}, \mathrm{Cu}$ and $\mathrm{Cd}$ in endurant plants distributed in an old smeltery, northeast China. Environ Geol 51:1043-1048

25. Mokgolele M, Likuku SA (2016) Preliminary investigation of transfer of metals from soil to vegetables: case study of Spinacia oleracea L. Afr J Environ Sci Technol 10:307-313

26. Saha N, Zaman M (2013) Evaluation of possible health risks of heavy metals by consumption of foodstuffs available in the central market of Rajshahi City, Bangladesh. Environ Monit Assess 185:3867-3878 
27. Yang Q-W, Xu Y, Liu S-J, He J-F, Long F-Y (2011) Concentration and potential health risk of heavy metals in market vegetables in Chongqing, China. Ecotoxicol Environ Saf 74:1664-1669

28. Liu X, Song Q, Tang Y, Li W, Xu J, Wu J, Wang F, Brookes PC (2013) Human health risk assessment of heavy metals in soil-vegetable system: a multi-medium analysis. Sci Total Environ 463:530-540

29. Smith RL (1995) EPA Region III risk-based concentration table. United States Environmental Protection Agency, pp 1-24

30. Islam MS, Ahmed MK, Habibullah-Al-Mamun M, Masunaga S (2014) Trace metals in soil and vegetables and associated health risk assessment. Environ Monit Assess 186:8727-8739

31. Tangahu BV, Abdullah SRS, Basri $\mathrm{H}$, Idris $\mathrm{M}$, Anuar $\mathrm{N}$, Mukhlisin $M$ (2011) A review on heavy metals ( $\mathrm{As}, \mathrm{Pb}$, and $\mathrm{Hg}$ ) uptake by plants through phytoremediation. Int J Chem Eng 2011:1-31

32. Van Ginneken L, Meers E, Guisson R, Ruttens A, Elst K, Tack FM, Vangronsveld J, Diels L, Dejonghe W (2007) Phytoremediation for heavy metal-contaminated soils combined with bioenergy production. J Environ Eng Landsc 15:227-236

33. Huq SF (1998) Critical environmental issues relating to tanning industries in Bangladesh. In: ACIAR proceeding, pp 22-28

34. FAO/WHO (2017) Evaluation of certain contaminants in food: eighty-third report of the joint FAO/WHO expert committee on food additives, pp 1-166

35. Clever J, Jie M (2014) China's maximum levels for contaminants in foods. USDA Foreign Agricultural Service GAIN Report CH14058, USDA Foreign Agricultural Service, Global Agricultural Information Network

36. Cho-Ruk K, Kurukote J, Supprung P, Vetayasuporn S (2006) Perennial plants in the phytoremediation of lead-contaminated soils. Biotechnology 5:1-4

37. Zhao F, Jiang R, Dunham S, McGrath S (2006) Cadmium uptake, translocation and tolerance in the hyperaccumulator Arabidopsis halleri. New Phytol 172:646-654

38. Prasad MNV, H.M.d.O. Freitas, (2003) Metal hyperaccumulation in plants: biodiversity prospecting for phytoremediation technology. Electron J Biotechnol 6:285-321

39. Rezvani M, Zaefarian F (2011) Bioaccumulation and translocation factors of cadmium and lead in'Aeluropus littoralis'. Aust J Agric Eng 2:114-119

40. Jolly YN, Islam A, Akbar S (2013) Transfer of metals from soil to vegetables and possible health risk assessment. SpringerPlus 2:1-8

41. Chopra AK, Pathak C (2012) Bioaccumulation and translocation efficiency of heavy metals in vegetables grown on long-term wastewater irrigated soil near Bindal River, Dehradun. Agric Res 1:157-164

42. Tyokumbur ET, Okorie T (2011) Bioconcentration of trace metals in the tissues of two leafy vegetables widely consumed in South West NigeriaBioconcentration of trace metals in the tissues of two leafy vegetables widely consumed in South West Nigeria. Biol Trace Elem Res 140:215-224

43. Thummajitsakul S, Thongkerd N, Pholmeesap B, Phankham P, Silprasit K (2020) Assessment of organophosphate and carbamate insecticides and heavy metal contamination in canal-grown water morning glory (Ipomoea aquatica Forssk) in Nakhon Nayok Province, Thailand. Appl Environ Res 42:26-42

44. Singh A, Sharma RK, Agrawal M, Marshall FM (2010) Health risk assessment of heavy metals via dietary intake of foodstuffs from the wastewater irrigated site of a dry tropical area of India. Food Chem Toxicol 48:611-619

45. Eid EM, El-Bebany AF, Alrumman SA, Hesham AE-L, Taher MA, Fawy KF (2017) Effects of different sewage sludge applications on heavy metal accumulation, growth and yield of spinach (Spinacia oleracea $\mathrm{L}$.)Effects of different sewage sludge applications on heavy metal accumulation, growth and yield of spinach (Spinacia oleracea L.). Int J Phytoremediat 19:340-347

46. Marschner H (2011) Marschner's mineral nutrition of higher plants. Academic Press 3:1-672

47. Page V, Feller U (2015) Heavy metals in crop plants: transport and redistribution processes on the whole plant level. Agronomy 5:447-463

48. Turner RG (1970) The subcelluar distribution of zinc and copper within the roots of metal-tolerant clones of Agrostis tenuis sibth. New Phytol 69:725-731

49. Page $V$, Weisskopf $L$, Feller $U$ (2006) Heavy metals in white lupin: uptake, root-to-shoot transfer and redistribution within the plant. New Phytol 171:329-341

50. Lee P-K, Choi B-Y, Kang M-J (2015) Assessment of mobility and bio-availability of heavy metals in dry depositions of asian dust and implications for environmental risk. Chemosphere 119:1411-1421

51. Dan TV, Raj SK, Saxena PK (2002) Cadmium and nickel uptake and accumulation in scented geranium (Pelargonium sp'.Frensham'). Water Air Soil Pollut 137:355-364

52. Sêkara A, Poniedzialek M, Ciura J, Jêdrszczyk E (2005) Cadmium and lead accumulation and distribution in the organs of nine crops: implications for phytoremediation. Pol J Environ Stud 14:509-516

53. Bronson RJ (1991) Iris: integrated risk information system database. Med Ref Serv Q 10:73-85

54. Lemly AD (1996) Evaluation of the hazard quotient method for risk assessment of selenium. Ecotoxicol Environ Saf 35:156-162

55. Zheng N, Wang Q, Zhang X, Zheng D, Zhang Z, Zhang S (2007) Population health risk due to dietary intake of heavy metals in the industrial area of Huludao City, China. Sci Total Environ 387:96-104

56. Marsee K, Woodruff TJ, Axelrad DA, Calafat AM, Swan SH (2006) Estimated daily phthalate exposures in a population of mothers of male infants exhibiting reduced anogenital distance. Environ Health Perspect 114:805-809

57. Tchounwou PB, Yedjou CG, Patlolla AK, Sutton DJ (2012) Heavy metal toxicity and the environment. Mol Clin Environ Toxicol 101:133-164

58. Sultana MS, Rana S, Yamazaki S, Aono T, Yoshida S (2017) Health risk assessment for carcinogenic and non-carcinogenic heavy metal exposures from vegetables and fruits of Bangladesh. Cogent Environ Sci 3:1-17

59. Li S, Zhang Q (2010) Risk assessment and seasonal variations of dissolved trace elements and heavy metals in the Upper Han River, China. J Hazard Mater 181:1051-1058

60. Järup L (2003) Hazards of heavy metal contamination. Br Med Bull 68:167-182

61. Belete T, Hussen A, Rao VM (2014) Determination of concentrations of selected heavy metals in cow's milk: Borena Zone, Ethiopia. J Health Sci 4:105-112

Publisher's Note Springer Nature remains neutral with regard to jurisdictional claims in published maps and institutional affiliations. 